\title{
Analisis Nilai-Nilai Pendidikan Karakter pada Ekstrakurikuler Seni Tari Tradisional di SDN Sawojajar 3 Malang
}

\author{
Zahna Karisma Daningtyas*, Retno Tri Wulandari, Nihayati \\ Universitas Negeri Malang, Jl. Semarang No. 5 Malang, Jawa Timur, Indonesia \\ *Penulis korespondensi, Surel: : zahnakharisma@gmail.com
}

Paper received: 2-1-2021; revised: 23-1-2021; accepted: 30-1-2021

\begin{abstract}
This study aims to (1) describe the process of extracurricular activities of traditional dance at Sawojajar 3 Malang Elementary School (2) to describe the values of character education contained in the traditional dance extracurricular activities at Sawojajar 3 Malang Elementary School. This research uses a qualitative approach with a descriptive type. Researcher as the main research instrument with research data source, namely the process of extracurricular activities of traditional dance. Collecting data using observation, interview, and documentation techniques. The results showed the values of character education in extracurricular traditional dance at Sawojajar 3 Malang Elementary School namely the process of extracurricular activities of traditional dance at Sawojajar 3 Malang Elementary School through 4 learning stages and 4 traditional dance materials. The four learning stages are pre- extracurricular activities for traditional dance, early extracurricular activities for traditional dance, core extracurricular activities for traditional dance, and final extracurricular activities for traditional dance. In the process of dance extracurricular activities through these 4 stages inserting habituation and giving examples of direct action. Religious character values, nationalist character values, community service character values, integrity character values, independent character values with creative sub- values have not been seen in extracurricular activities of traditional dance.
\end{abstract}

Keywords: traditional dance extracurricular activities; character education; elementary school

\begin{abstract}
Abstrak
Penelitian ini bertujuan untuk (1) mendeskripsikan proses kegiatan ekstrakurikuler seni tari tradisional di SDN Sawojajar 3 Malang (2) mendeskripsikan nilai-nilai pendidikan karakter yang terdapat pada ekstrakurikuler seni tari tradisional di SDN Sawojajar 3 Malang. Penelitian ini menggunakan pendekatan kualitatif dengan jenis deskriptif. Peneliti sebagai instrumen penelitian utama dengan sumber data penelitian yaitu proses kegiatan ekstrakurikuler seni tari tradisional. Pengumpulan data menggunakan teknik observasi, wawancara, dan dokumentasi. Hasil penelitian menunjukkan bahwa nilai-nilai pendidikan karakter pada ekstrakurikuler seni tari tradisional di SDN Sawojajar 3 Malang yaitu proses kegiatan ekstrakurikuler seni tari tradisional di SDN Sawojajar 3 Malang melalui 4 tahap pembelajaran dan 4 Materi tari tradisional. Empat tahapan pembelajaran yaitu kegiatan pra-ekstrakurikuler seni tari tradisional, kegiatan awal ekstrakurikuler seni tari tradisional, kegiatan inti ekstrakurikuler seni tari tradisional, dan kegiatan akhir ekstrakurikuler seni tari tradisional. Dalam proses kegiatan ekstrakurikuler seni tari melalui 4 tahapan tersebut menyisipkan pembiasaan dan pemberian contoh tindakan langsung. Nilai karakter religius, nilai karakter nasionalis, nilai karakter gotong royong, nilai karakter integritas, nilai karakter mandiri dengan sub- nilai kreatif belum terlihat pada kegiatan ekstrakurikuler seni tari tradisional.
\end{abstract}

Kata kunci: ekstrakurikuler seni tari tradisional; pendidikan karakter; sekolah dasar

\section{Pendahuluan}

Pendidikan seni termasuk bagian di dalam kurikulum sekolah dasar yang termuat dalam konsep pendidikan nasional. Dalam pendidikan nasional bersifat "multi fungsi" dengan 
mengembangkan sumber daya manusia dan meningkatkan mutu individu tersebut dalam kehidupan sehari-harinya. Sesuai dengan pendapat Sumanto (2012) pendidikan seni adalah komponen dalam kurikulum sekolah yang di setiap kegiatan memiliki seninya yang berorientasi pada proses berpikir kreatif yang akan meningkatkan mutu generasi bangsa yaitu mencerdaskan dan pembentukan karakter. Dalam pendidikan seni budaya memiliki banyak muatan pembelajaran yaitu seni tari, seni musik, seni drama, seni sastra dan seni rupa.

Seni tari menjadi salah satu dari ragam seni kebudayaan bangsa yang menggunakan unsur gerak pada tubuh manusia. Menurut Sumanto (2012) seni tari merupakan bagian pendidikan seni budaya yang membentuk karakter. Menjadikan seni tari mampu memberikan pendidikan karakter pada peserta didik melalui pembiasaan yang dilakukan pada kegiatan seni tari. Hasil penelitian Hartini dan Rudyanto (2019) seni tari tradisional mempunyai tujuan dalam penumbuhan karakter positif seperti pada tari orek-orek dari Ngawi yang memiliki pesan moral positif dalam setiap gerakannya dan dapat diajarkan dengan mudah pada

Pendidikan karakter salah satu cara untuk mewujudkan pondasi nilai-nilai karakter yang baik dan sesuai dengan kebudayaan bangsa. Ini sesuai yang tertuang pada Kementerian Pendidikan Nasional dalam Komalasari dan Saparudin (2017) pendidikan karakter adalah pendidikan budi pekerti, pendidikan nilai, pendidikan moral, pendidikan watak yang mempunyai tujuan untuk mengembangkan kemampuan peserta didik untuk memberikan keputusan baik - buruk, mengambil dan menetapkan yang baik dalam kehidupan sosial dalam sehari-hari. Menurut Budhiman staf ahli kemendikbud bidang pembangunan (2017) pada gerakan penguatan pendidikan karakter merupakan sebagai fondasi dan ruh utama pendidikan. Oleh Sebab itu pendidikan karakter di sekolah harus dilaksanakan secara matang dan baik karena memengaruhi dalam pembentukan karakter peserta didik agar mempunyai nilai-nilai karakter.

Ekstrakurikuler menjadi kegiatan yang mampu menanamkan pendidikan karakter. Ekstrakurikuler merupakan fasilitas pengembangan bakat dan minat yang berbeda-beda sesuai kebutuhan anak dan nilai karakter baik moral, sikap, maupun kreatifitas yang dilaksanakan di luar jam sekolah (Jasman, 2018). Sesuai pendapat yang telah disampaikan di atas kegiatan ekstrakurikuler dengan media seni tari dapat menjadi salah satu pilihan untuk pembentukan pendidikan karakter di luar jam sekolah atau kegiatan akademis. Kegiatan ekstrakurikuler seni tari diharapkan dapat memberikan solusi untuk sekolah memfasilitasi pendidikan karakter yang lebih baik dan menyenangkan.

Kegiatan ekstrakurikuler seni tari merupakan kegiatan pendidikan yang dilakukan di luar jam pelajaran yang berfungsi untuk membantu pembentukan pendidikan karakter. Hasil penelitian Fadillah (2016) menunjukkan bahwa pembelajaran seni tari pada kegiatan ekstrakurikuler seni tari membantu dalam mengembangkan nilai karakter pada peserta didik. Dapat disimpulkan ekstrakurikuler seni tari mampu menjadi wadah dalam mengembangkan pendidikan karakter pada anak usia sekolah dasar. Nilai-nilai karakter yang sesuai budaya bangsa mampu terserap pada diri anak dimulai pada usia sekolah dasar.

Berdasarkan hasil observasi yang peneliti lakukan pada hari Kamis, 6 Januari 2020 di SDN Sawojajar 3 Malang diperoleh informasi dari kepala sekolah Ibu Dewi Asriningsih, S.Pd, SDN Sawojajar 3 Malang menjadi lembaga salah satu pendidikan formal yang memberikan pendidikan karakter kepada peserta didik yang berada di kota Malang melalui kegiatan intrakurikuler dan ekstrakurikuler. Dalam memberikan pendidikan karakter SDN Sawojajar 3 
Malang memfasilitasi peserta didik dengan kegiatan ekstrakurikuler seni tari tradisional yang terus ditingkatkan dari tahun ketahun sejak tahun 2015 dalam fasilitas hingga pembelajarannya. Kegiatan ekstrakurikuler seni tari tradisional dilaksanakan secara rutin seminggu sekali setiap hari kamis pada pukul 13:00 - 14:30 dengan dilatih oleh Ibu Luluk Atil Mabruroh, S.Pd. selaku guru tari dalam ekstrakurikuler seni tari tradisional yang memiliki kompeten di bidang seni tari tradisional. Kegiatan ekstrakurikuler seni tari tradisional diikuti 75 peserta didik dari kelas I hingga kelas V.

Pada proses kegiatan ekstrakurikuler seni tari tradisional di SDN Sawojajar 3 Malang sudah direncanakan dan dilaksanakan dengan baik oleh sekolah maupun guru tari dari fasilitas hingga pembiasaan untuk membentuk karakter kepada peserta didik. Program kegiatan ekstrakurikuler seni tari tradisional yang sudah baik dan terus ditingkatkan oleh sekolah mampu menjadikan peserta didik maksimal dalam mengembangkan minat dan bakatnya seperti mengikutsertakan peserta didik dalam perlombaan seni tari tradisional serta peserta didik memiliki nilai karakter dan budi pekerti yang baik dari pembiasaan yang dilakukan oleh sekolah. Namun masih belum diketahui dalam menerapkan pendidikan karakter SDN Sawojajar 3 Malang pada kegiatan ekstrakurikuler seni tari tradisional sudah sesuai atau tidak dengan PPK (Penguatan Pendidikan Karakter) pada Kurikulum 2013.

Pada penelitian terdahulu mengenai pendidikan karakter pada ekstrakurikuler seni tari memang sudah ada. Penelitian oleh Nurani Fadillah (2016) "Pelaksanaan Pembelajaran Ekstrakurikuler Seni Tari Tradisional Dalam Membentuk Karakter Pada Peserta Didik Kelas Tinggi Di SDN Tambakaji 01 Semarang" ditemukan nilai karakter pada ekstrakurikuler seni tari tradisional untuk membentuk karakter peserta didik kelas tinggi. Penelitian selanjutnya oleh Sulistyaningsih (2018) mengenai “Nilai-Nilai Pendidikan Karakter Dalam Ekstrakurikuler Seni Tari Di MI Al-Ihsan Medari" ditemukan nilai-nilai karakter pada ekstrakurikuler seni tari berbasis agama untuk membentuk karakter pada peserta didik Madrasah Ibtidaiyah. Perbedaan penelitian analisis pendidikan karakter pada ekstrakurikuler seni tari yang dilakukan peneliti - peneliti terdahulu terletak pada muatan seni tari dan objek peserta didik.

Berdasarkan latar belakang yang telah dipaparkan peneliti melakukan penelitian mengenai pendidikan karakter pada ekstrakurikuler seni tari lebih lanjut. Judul penelitian yang dipilih sesuai latar belakang masalah yaitu "Analisis Nilai-Nilai Pendidikan Karakter Pada Ekstrakurikuler Seni Tari Tradisional Di SDN 3 Sawojajar". Peneliti akan menganalisis pendidikan karakter pada ekstrakurikuler seni tari lebih lanjut dengan menggunakan muatan tari tradisional dengan objek peserta didik kelas kelas I hingga kelas V. Alasan peneliti menganalisis pendidikan karakter pada ekstrakurikuler seni tari tradisional di SDN Sawojajar 3 Malang pada peserta didik kelas I sampai kelas V karena berdasarkan fakta dan fenomena di lapangan masih banyaknya sekolah dan guru tari di kota Malang yang masih belum mengetahui manfaat dari kegiatan ekstrakurikuler seni tari tradisional dalam menerapkan pendidikan karakter di sekolah untuk membentuk nilai karakter yang sesuai budaya bangsa pada peserta didik dan untuk mengetahui penerapan pendidikan karakter pada kegiatan ekstrakurikuler seni tari tradisional di SDN Sawojajar 3 Malang sudah sesuai atau tidak dengan PPK (Penguatan Pendidikan Karakter) kurikulum 2013. 


\section{Metode}

Penelitian ini menggunakan pendekatan kualitatif. Penelitian kualitatif adalah penelitian yang dilakukan pada kondisi objek alamiah yang menyangkut situasi sosial di mana peneliti sebagai instrumen kunci, pengambilan sampel dan sumber data dilakukan secara purposive dan snowball, dengan teknik pengumpulan data triangulasi, analisis data bersifat induktif dan hasil penelitian lebih menekankan makna tidak untuk digeneralisasikan pada populasi, dan dituliskan secara deskripsi oleh kata-kata (Sugiyono, 2016). Penelitian ini menggunakan metode etnografi yang bertujuan menganalisis kegiatan kebudayaan atau perilaku peserta didik yang akan diteliti. Hasil penelitian ini dianalisis berupa deskriptif sehingga penelitian ini tergolong penelitian jenis deskriptif kualitatif. deskriptif kualitatif merupakan jenis penelitian yang dipakai untuk menjelaskan atau menggambarkan dari hasil penelitian (Sugiyono, 2009).

Kehadiran peneliti adalah kunci dari penelitian atau peran utamanya dalam penelitian kualitatif. Penelitian kualitatif adalah penelitian yang dilakukan pada kondisi objek alamiah yang menyangkut situasi sosial di mana peneliti sebagai instrumen kunci (Sugiyono, 2016). Kegiatan penelitian ini, peneliti langsung ke lapangan dengan melakukan kegiatan mengumpulkan data melalui observasi kegiatan yang diobservasi yaitu kegiatan ekstrakurikuler seni tari tradisional yang diikuti oleh peserta didik SDN Sawojajar 3 Malang untuk membentuk nilai-nilai karakter yang ada pada Penguatan Pendidikan Karakter (PPK), melakukan wawancara terkait penelitian, melakukan dokumentasi selama kegiatan observasi berlangsung.

Penelitian dilaksanakan di SDN Sawojajar 3 Malang, alasan pengambilan lokasi penelitian dikarenakan peneliti melihat pelaksanaaan kegiatan ekstrakurikuler seni tari tradisional sudah sangat baik di mana pembina kegiatan ekstrakurikuler seni tari tradisional dibina oleh guru yang kompeten di bidang seni tari tradisional dan antusias peserta didik untuk mengikuti kegiatan ekstrakurikuler seni tari tradisional di SDN Sawojajar 3 Malang sangat besar.

Data yang dikumpulkan oleh peneliti yaitu proses kegiatan ekstrakurikuler seni tari tradisional dan nilai-nilai pendidikan karakter yang terdapat dari kegiatan ekstrakurikuler seni tari tradisional pada peserta didik kelas I hingga kelas $V$ yang didapat melalui hasil analisis nilai-nilai pendidikan karakter pada kegiatan ekstrakurikuler seni tari tradisional dan didukung dengan observasi, wawancara dan dokumentasi. Jumlah peserta didik yang dijadikan sebagai sumber data penelitian sebanyak 75 peserta didik.

Teknik pengumpulan data adalah tahap utama dalam penelitian, karena tujuan penelitian merupakan mencari dan mendapatkan data (Sugiyono, 2016). Teknik pengumpulan data yang digunakan dalam penelitian ini antara lain, Observasi, wawancara dan dokumentasi.

Instrumen penelitian ini menggunakan instrumen atau alat, instrumen penelitian dalam penelitian kualitatif adalah sebagai pelengkap data dari peneliti itu sendiri agar data dan sumber data yang diambil berkualitas (Sugiyono, 2016). Dalam penelitian ini peneliti sebagai instrumen utama yang mempunyai tugas mengumpulkan, menganalisis, menafsirkan dan melaporkan data, penelitian untuk data nilai-nilai pendidikan karakter pada ekstrakurikuler seni tari tradisional akan didapat dengan menggunakan metode wawancara, observasi dan studi dokumen, dalam mengumpulkan data peneliti membutuhkan instrumen pedoman wawancara, observasi, dokumentasi, dan indikator nilai karakter yang ada pada ekstrakurikuler seni tari tradisional. 
Tahap selanjutnya analisis data yang menyusun data secara sistematis yang diperoleh dari pengumpulan data. Analisis data merupakan proses mendapatkan dan menyusun secara sistematis yang didapat dari hasil observasi, wawancara dan dokumentasi dengan melakukan pengorganisasian data ke dalam kategori lalu menjelaskan pada unit - unit, memilih mana yang penting atau tidak untuk data penelitian dan membuat kesimpulan hingga mampu dipahami orang lain dan masyarakat. (Sugiyono, 2016) dalam penelitian ini peneliti menggunakan model Miles and Huberman yaitu data reduction, data display, conclusing drawing/verification.

Teknik keabsahan data mempunyai tujuan untuk menguji validitas data yang didapat dalam penelitian kualitatif. Penelitian ini menggunakan metode Triangulasi untuk teknik keabsahan datanya. Menurut (Sugiyono, 2017) Triangulasi bersifat menggabungkan dengan pengecekan data dari berbagai data dan sumber data dengan berbagai waktu dan berbagai cara. Peneliti akan melakukan teknik triangulasi dengan pengumpulan data yaitu observasi, wawancara, dan dokumentasi.

\section{Hasil dan Pembahasan}

Penelitian ini menghasilkan analisis Proses pelaksanaan kegiatan ekstrakurikuler seni tari tradisional di SDN Sawojajar 3 Malang yaitu dengan mengajarkan tari-tarian tradisional dengan disisipkan pembiasaan karakter yang sesuai dengan PPK. Pelaksanaannya dilaksanakan setiap minggu pada hari kamis mulai pukul 13:00-14:30. Saat melaksanakan latihan guru tari mengajarkan tari dengan menyisipkan pembiasaan karakter yang ingin diterapkan kepada peserta didik. Pembiasaan dilakukan untuk membentuk karakter peserta didik yang sesuai pada PPK, selain itu guru juga memberikan contoh langsung perilaku perilaku yang baik agar dapat dijadikan panutan oleh peserta didik dalam bertindak dan berperilaku. Berdasarkan hasil data wawancara yang peneliti lakukan dengan guru tari pada 13 Mei 2020 pelaksanaan proses kegiatan pada ekstrakurikuler seni tari tradisional memiliki empat materi tari tradisional dan empat tahap pembelajaran yang diajarkan.

Empat materi tari tradisional yaitu tari lilin, tari oglek, tari kebat ngigel, dan tari ujung alit untuk tahap dalam proses pelaksanaan kegiatan ekstrakurikuler seni tari tradisional di SDN Sawojajar 3 Malang yaitu kegiatan pra- ekstrakurikuler seni tari tradisional, kegiatan awal ekstrakurikuler seni tari tradisional, kegiatan inti ekstrakurikuler seni tari tradisional, dan kegiatan akhir ekstrakurikuler seni tari tradisional. Setiap tahap guru akan menyampaikan materi agar peserta didik lebih mudah memahami selain itu guru juga menyisipkan pembiasaan untuk membentuk karakter peserta didik dan ditunjang dengan komponen seperti, media, metode, dan alat penunjang untuk membiasakan pembelajaran nilai karakter kepada peserta didik agar pelaksanaan ekstrakurikuler seni tari tradisional terlaksana dengan baik. Berikut paparan kegiatan yang menyatakan bahwa adanya penanaman nilai-nilai pendidikan karakter pada ekstrakurikuler seni tari tradisional di SDN 3 Sawojajar Malang.

\subsection{Nilai karakter religius}

\subsubsection{Persahabatan}

Dari hasil observasi kegiatan ekstrakurikuler seni tari tradisional membiasakan untuk menanamkan nilai karakter religius sub- nilai persahabatan kepada peserta didik dengan sikap peserta didik yang selalu mengapresiasi hasil belajar temannya dalam menguasai gerakan tari tradisional dan saling mendukung untuk mampu menguasai gerakan tari tradisional. Sikap 
peserta didik lainnya yang menggambarkan karakter persahabatan ditunjukkan peserta didik saat saling membantu saat belajar bersama gerakan tari secara mandiri peserta didik yang sudah mampu dalam menguasai gerakan tari akan membantu temannya yang belum mampu menguasai gerakan tari tradisional. Sehingga dalam kegiatan ekstrakurikuler seni tari tradisional di SDN Sawojajar 3 Malang terdapat nilai karakter religius sub- nilai persahabatan di dalamnya.

\subsubsection{Mencintai lingkungan}

Berdasarkan hasil observasi kegiatan ekstrakurikuler seni tari tradisional membiasakan peserta didik dalam hal kebersihan, ini merupakan penanaman nilai karakter religius sub- nilai mencintai lingkungan. Peserta didik dibiasakan menjaga kebersihan lingkungan tempat latihan ekstrakurikuler seni tari tradisional dengan saling membantu membersihkan tempat latihan sebelum dan sesudah kegiatan ekstrakurikuler seni tari tradisional. Kebiasaan ini mengajarkan nilai religius karena kebersihan sebagian dari iman, sub- nilai mencintai lingkungan ini mampu meningkatkan kesadaran peserta didik tentang kebersihan sekitar karena untuk kenyamanan belajar peserta didik sendiri. Sehingga dalam kegiatan ekstrakurikuler seni tari tradisional di SDN Sawojajar 3 Malang terdapat nilai karakter religius sub- nilai mencintai lingkungan didalamnya.

\subsection{Nilai karakter nasionalisme}

\subsubsection{Menjaga kekayaan budaya bangsa}

Karakter menjaga kekayaan budaya bangsa sudah dimiliki oleh peserta didik SDN Sawojajar 3 Malang yang banyak mengikuti ekstrakurikuler seni tari tradisional. Ini terlihat dari hasil wawancara kepada peserta didik yang lebih memilih belajar tari tradisional dan lebih menyukai mengikuti kegiatan tari tradisional daripada kegiatan ekstrakurikuler modern. Sikap menjaga kekayaan budaya bangsa juga terlihat dari peserta didik saat belajar gerakan tari tradisional peserta didik dengan sangat bersemangat dan merasa bangga mampu menguasai gerakan tari tradisional.

\subsubsection{Unggul dan berprestasi}

Dari hasil wawancara kepada peserta didik sikap unggul dan berprestasi sudah dimiliki peserta didik, ini terlihat dari sikap peserta didik dalam memotivasi diri untuk dapat menguasai gerakan tari dengan baik dan sikap unggul dan berprestasi juga terlihat saat peserta didik memiliki rasa ingin menjadi terbaik diantara teman-temannya dalam menguasai gerakan. Menjadikan peserta didik belajar gerakan tari tradisional dengan maksimal agar mampu mengikuti lomba tari yang akan diikuti ekstrakurikuler seni tari tradisional SDN Sawojajar 3 Malang. Sehingga pada kegiatan ekstrakurikuler seni tari tradisional terdapat nilai karakter nasionalis dengan sub- nilai karakter unggul dan berprestasi.

\subsubsection{Disiplin}

Berdasarkan hasil observasi kegiatan ekstrakurikuler seni tari tradisional sudah menanamkan kedisiplinan di dalamnya baik disiplin waktu, disiplin sikap izin apabila berhalangan hadir, dan sikap disiplin membawa properti dan memakai pakaian latihan. Kedisiplinan diterapkan setiap kegiatan ekstrakurikuler seni tari tradisional dilaksanakan. 
Sikap disiplin masuk dalam nilai karakter nasionalis dengan sub- nilai karakter disiplin. Dalam kegiatan ekstrakurikuler seni tari tradisional di SDN Sawojajar 3 Malang sudah terdapat penanaman nilai karakter nasionalis dengan sub- nilai karakter disiplin.

\subsection{Nilai karakter mandiri}

\subsubsection{Etos kerja (kerja keras)}

Dari hasil observasi kegiatan ekstrakurikuler seni tari tradisional di SDN Sawojajar 3 Malang ini terdapat sikap kerja keras di dalam kegiatan. Sikap kerja keras peserta didik yang mau berusaha untuk mampu menguasai gerakan tari tradisional. Sikap etos kerja (kerja sama) masuk dalam nilai karakter mandiri dengan sub- nilai karakter etos kerja (kerja keras). Dalam kegiatan ekstrakurikuler seni tari tradisional di SDN Sawojajar 3 Malang sudah terdapat penanaman nilai karakter mandiri dengan sub- nilai karakter etos kerja (kerja keras).

\subsubsection{Kreatif}

Berdasarkan hasil observasi menunjukkan bahwa kegiatan ekstrakurikuler seni tari tradisional di SDN 3 Sawojajar Malang belum melatih sikap kreatif pada peserta didik. Peserta didik tidak terlalu dilibatkan dalam pembuatan karya tari seperti eksplorasi gerakan ataupun pola lantai. Peserta didik hanya diajarkan gerakan tari dan pola lantai yang sudah ditentukan oleh guru tari. Sikap kreatif masuk dalam nilai karakter mandiri dengan sub- nilai karakter kreatif. Dalam kegiatan ekstrakurikuler seni tari tradisional di SDN Sawojajar 3 Malang belum menanamkan karakter kreatif peserta didik pada saat kegiatan ekstrakurikuler seni tari tradisional di SDN 3 Sawojajar Malang.

\subsection{Nilai karakter gotong royong}

\subsubsection{Menghargai}

Berdasarkan hasil wawancara dan observasi sikap menghargai sudah ditanamkan dalam kegiatan ekstrakurikuler seni tari tradisional di SDN Sawojajar 3 Malang. Sikap menghargai dan saling mendukung yang dilakukan peserta didik untuk mengapresiasi pencapaian yang sudah didapat oleh peserta didik lain. Sikap menghargai masuk dalam nilai karakter gotong royong dengan sub- nilai karakter menghargai. Dalam kegiatan ekstrakurikuler seni tari tradisional di SDN Sawojajar 3 Malang sudah terdapat penanaman nilai karakter gotong royong dengan sub- nilai karakter menghargai.

\subsubsection{Kerja sama}

Dari hasil observasi kegiatan ekstrakurikuler seni tari tradisional di SDN 3 Sawojajar Malang sudah menanamkan sikap kerja sama, seperti belajar bersama teman kelompok, saling membantu antar teman. Baik saat belajar bersama ataupun belajar mandiri, dan saling mengingatkan antar teman serta menjaga kekompakan kelompok. Peserta didik selalu bekerja sama saat melakukan kegiatan belajar bersama tari tradisional terutama pada saat belajar bersama kelompoknya. Sikap kerja sama masuk dalam nilai karakter gotong royong dengan sub- nilai karakter kerja sama. Dalam kegiatan ekstrakurikuler seni tari tradisional di SDN Sawojajar 3 Malang sudah terdapat penanaman pembentukan nilai karakter gotong royong dengan sub- nilai karakter kerja sama. 


\subsubsection{Tolong menolong}

Berdasarkan hasil observasi dan wawancara kegiatan ekstrakurikuler seni tari tradisional di SDN Sawojajar 3 Malang ini terdapat sikap tolong menolong didalam kegiatan. Sikap tolong menolong yang dimiliki peserta didik terlihat dengan adanya peserta didik yang sudah mampu menguasai gerakan tari tradisional dengan kesadarannya, mau membantu temannya yang belum mampu menguasai gerakan tari tradisional. Sikap tolong menolong lainnya yang dimiliki peserta didik saat antar peserta didik saling membantu untuk menjaga kebersihan tempat kegiatan latihan tari tradisional. Sikap tolong menolong masuk dalam nilai karakter gotong royong dengan sub- nilai karakter tolong menolong. Dalam kegiatan ekstrakurikuler seni tari tradisional di SDN Sawojajar 3 Malang sudah sudah menanamkan pembentukan nilai karakter gotong royong dengan sub- nilai karakter tolong menolong.

\subsection{Nilai karakter integritas}

\subsubsection{Kejujuran}

Dari hasil wawancara dan observasi kegiatan ekstrakurikuler seni tari tradisional di SDN 3 Sawojajar Malang sudah menanamkan sikap kejujuran di dalam kegiatan. sikap kejujuran peserta didik ditunjuk gerakkan saat tidak bisa hadir mengikuti kegiatan ekstrakurikuler seni tari tradisional. Peserta didik akan izin kepada guru tari langsung atau teman untuk disampaikan ke guru tari bahwa tidak bisa mengikuti kegiatan tari tradisional. Sikap kejujuran masuk dalam nilai karakter integritas dengan sub- nilai karakter kejujuran. Dalam kegiatan ekstrakurikuler seni tari tradisional di SDN Sawojajar 3 Malang sudah menanamkan pembentukan nilai karakter integritas dengan sub- nilai karakter kejujuran.

\subsubsection{Tanggung jawab}

Dari hasil observasi kegiatan ekstrakurikuler seni tari tradisional di SDN 3 Sawojajar Malang sudah menanamkan sikap tanggung jawab dalam kegiatan. Sikap kejujuran yang dimiliki peserta didik saat kegiatan latihan, peserta didik terlihat memiliki kemauan yang tinggi untuk menguasai gerakan tari tradisional dengan baik. Sikap peserta didik yang bertanggung jawab juga karena guru tari membiasakan peserta didik memiliki target di setiap pertemuan untuk menguasai gerakan tari tradisional yang diberikan saat pertemuan sebelumnya. Ini menjadikan peserta didik terbiasa dengan tanggung jawab yang harus diselesaikan yakni menguasai gerakan tari untuk diapresiasi oleh guru tari saat waktu apresiasi. Sikap tanggung jawab masuk dalam nilai karakter integritas dengan sub- nilai karakter tanggung jawab. Dalam kegiatan ekstrakurikuler seni tari tradisional di SDN Sawojajar 3 Malang sudah menanamkan pembentukan nilai karakter integritas dengan subnilai karakter tanggung jawab.

Pembahasan pada hasil data observasi dan wawancara proses kegiatan ekstrakurikuler seni tari tradisional guru tari menyisipkan pembiasaan - pembiasaan kepada peserta didik melalui kegiatan ekstrakurikuler seni tari tradisional untuk menerapkan pendidikan karakter dan membentuk nilai karakter kepada peserta didik. Berdasarkan temuan peneliti tersebut sesuai dengan hasil penelitian Lestari dan Sindhuredja (2016) menunjukkan pelaksanaan kegiatan ekstrakurikuler seni tari untuk menerapkan pendidikan karakter dilaksanakan dengan pembiasaan treatment pada peserta didik dalam pelaksanaannya sehingga dapat terbentuk pribadi peserta didik yang mulia dan berkarakter. Melalui pembiasaan - pembiasaan 
yang dilaksanakan dalam kegiatan ekstrakurikuler seni tari untuk menerapkan pendidikan karakter mampu membentuk nilai karakter peserta didik sesuai kebudayaan bangsa.

Pembiasaan yang dilakukan guru tari kepada peserta didik, seperti menyisipkan nilainilai karakter pada kegiatan ekstrakurikuler seni tari tradisional. nilai-nilai karakter yang disisipkan oleh guru tari pada kegiatan latihan. Peserta didik dibiasakan untuk memiliki karakter persahabatan, mencintai lingkungan, menjaga kekayaan budaya bangsa, unggul dan berprestasi, disiplin, etos kerja (kerja keras), menghargai, kerja sama, tolong menolong, kejujuran, dan tanggung jawab. Pembiasaan yang dilakukan guru tari kepada peserta didik ini dilakukan secara berulang-ulang untuk membiasakan peserta didik dalam bertindak pada suatu hal. Hasil penelitian tersebut sejalan dengan teori conditioning menurut pavlov dan watson yang menyatakan bahwa teori ini mengatakan segala tingkah laku manusia juga merupakan hasil latihan atau kebiasaan yang bereaksi terhadap syarat atau perangsang tertentu yang dialami dalam kehidupannya (Sahlan, 2018:42). Membiasakan peserta didik melakukan kegiatan yang mencerminkan nilai-nilai karakter secara terus menerus, akan melatih peserta didik terbiasa untuk memiliki nilai-nilai karakter. Pembiasaan yang dilakukan oleh guru tari dapat dengan pemberian contoh tindakan langsung kepada peserta didik.

Pada kegiatan ekstrakurikuler seni tari tradisional guru tari akan menerapkan nilai karakter melalui pemberian contoh-contoh tindakan langsung yang dapat dicontoh dan dijadikan panutan oleh peserta didik. Guru tari selalu berperilaku disiplin dalam menaati aturan, datang tepat waktu serta memberikan contoh berpakaian untuk latihan tari,seperti menggunakan kaos dan celana olahraga untuk memberikan contoh langsung kepada peserta didik. Guru tari juga mencontohkan sikap tanggung jawab dengan mengajarkan materi tari sampai peserta didik menguasai gerakan tari dengan baik. pemberian tindakan contoh langsung oleh guru tari juga dalam hal menjaga kebersihan di mana guru tari juga ikut andil dalam menjaga kebersihan tempat ekstrakurikuler. Peserta didik juga diajarkan tindakan langsung dengan membiasakan peserta didik kerja keras menguasai gerakan dan kerja sama dalam kelompok. Kerja sama diajarkan melalui metode pembelajaran kelompok yang dilakukan oleh guru tari kepada peserta didik karena pengajaran tari diajarkan secara kelompok sesuai tingkatan kelas dan materi tari. Pemberian contoh tindakan langsung ini dihubungkan dengan kegiatan sehari-hari untuk membiasakan peserta didik bertindak sesuai nilai-nilai karakter. Hasil temuan peneliti ini sejalan dengan pendapat berikut, Penerapan nilai karakter yang termuat dalam seni tari dapat dihubungkan dengan kegiatan di kehidupan sehari-hari (Rosala, 2016:24). Melalui kegiatan ekstrakurikuler seni tari tradisional penerapan pendidikan karakter akan lebih mudah diberikan kepada peserta didik. Pembiasaan bertindak langsung yang diberikan kepada peserta didik akan membiasakan untuk selalu melakukan tindakan yang mencerminkan nilai-nilai karakter.

Kegiatan ekstrakurikuler seni tari tradisional di SDN Sawojajar 3 Malang memiliki dua tujuan yaitu menjadi wadah untuk mengembangkan potensi bakat dan minat peserta didik dan menjadi tempat untuk menerapkan nilai-nilai karakter sesuai karakter budaya bangsa. Pada ekstrakurikuler seni tari tradisional peserta didik diberikan ruang untuk mengembangkan bakat dan minatnya dalam seni tari tradisional. Sekolah sangat mendukung peserta didik yang memiliki potensi dan prestasi dalam bidang seni tari tradisional. Selain itu Kegiatan ekstrakurikuler seni tari tradisional juga menjadi tempat untuk penanaman nilai-nilai karakter kepada peserta didik dengan cara membiasakan peserta didik dengan kegiatan dan tindakan yang mencerminkan nilai-nilai karakter. Berdasarkan temuan peneliti tersebut sejalan dengan 
pendapat yang menyatakan ekstrakurikuler merupakan fasilitas pengembangan bakat dan minat yang berbeda-beda sesuai kebutuhan anak dan nilai karakter baik moral, sikap, maupun kreatifitas yang dilaksanakan di luar jam sekolah (Jasman, 2018:12). Adanya wadah untuk peserta didik berkembang akan memudahkan dalam pembentukan karakter dan pengembangan potensi peserta didik.

Pada nilai-nilai karakter yang terkandung pada kegiatan ekstrakurikuler seni tari tradisional di SDN Sawojajar 3 Malang merupakan nilai-nilai karakter yang mencerminkan budaya bangsa. Lima nilai utama dan 18 sub- nilai karakter dalam program Penguatan Pendidikan Karakter (PPK) merupakan rujukan sekolah dalam penanaman nilai karakter kepada peserta didik. Nilai karakter yang terdapat pada kegiatan ekstrakurikuler seni tari tradisional ada 12 sub- nilai karakter adalah karakter persahabatan, mencintai lingkungan, menjaga kekayaan budaya bangsa, unggul dan berprestasi, disiplin, etos kerja (kerja keras), menghargai, kerja sama, tolong menolong, kejujuran, dan tanggung jawab belum terpenuhi 18 sub- nilai karakter. Penanaman nilai karakter tersebut ini selalu disisipkan pada tahap-tahapan pembelajaran di kegiatan ekstrakurikuler seni tari tradisional. Berdasarkan temuan peneliti tersebut sesuai dengan hasil penelitian Lestari dan Sindhuredja (2016) Dalam pelaksanaan ekstrakurikuler seni tari tradisional nilai-nilai karakter yang ditunjukkan hanya 8 nilai karakter yaitu religius, kerjasama, toleransi, rasa percaya diri, sabar, disiplin, tanggungjawab dan cinta tanah air belum dapat teraktualisasi 18 sub- nilai karakter yang sesuai dengan pendidikan karakter oleh Kementerian Pendidikan Nasional. Melalui kegiatan ekstrakurikuler seni tari dengan muatan seni tari tradisional pendidikan karakter mampu dikembangkan sekolah untuk menanamkan sub- nilai karakter yang lebih yaitu 12 sub- nilai karakter yang hampir teraktualisasi 18 sub- nilai karakter.

Nilai-nilai yang terdapat pada ekstrakurikuler seni tari tradisional di SDN Sawojajar 3 Malang sudah terlihat sejak peneliti melaksanakan penelitian pada minggu pertama hingga minggu terakhir. Peserta didik terlihat memiliki karakter persahabatan, mencintai lingkungan, menjaga kekayaan budaya bangsa, unggul dan berprestasi, disiplin, etos kerja (kerja keras), menghargai, kerja sama, tolong menolong, kejujuran, dan tanggung jawab dalam bersikap saat mengikuti ekstrakurikuler seni tari tradisional. Hasil penelitian peneliti lakukan sependapat dengan penerapan nilai karakter yang termuat dalam seni tari dapat dihubungkan dengan kegiatan di kehidupan sehari-hari (Rosala, 2016:24). Penerapan nilai karakter yang termuat dalam ekstrakurikuler seni tari tradisional dapat dikaitkan dengan tindakan di kehidupan sehari-hari, seperti nilai karakter persahabatan, unggul dan berprestasi, etos kerja (kerja keras), menghargai, kerja sama, dan kejujuran. Melalui kegiatan ekstrakurikuler seni tari tradisional dibiasakan sejak dini secara terus menerus agar peserta didik memiliki sikap mencintai lingkungan, menjaga kekayaan budaya bangsa, disiplin, tolong menolong dan tanggung jawab.

\section{Simpulan}

Berdasarkan hasil penelitian dan pembahasan, dapat disimpulkan bahwa analisis nilainilai pendidikan karakter pada ekstrakurikuler seni tari tradisional SDN Sawojajar 3 Malang memiliki proses pelaksanaan kegiatan ekstrakurikuler seni tari tradisional yang digunakan oleh guru tari yaitu melalui 4 tahap pembelajaran dan 4 Materi tari tradisional yang akan diberikan kepada peserta didik. Dalam 4 tahap pembelajaran yaitu kegiatan praekstrakurikuler seni tari tradisional, kegiatan awal ekstrakurikuler seni tari tradisional, kegiatan inti ekstrakurikuler seni tari tradisional, dan kegiatan akhir ekstrakurikuler seni tari 
tradisional. Dalam Proses pelaksanaan kegiatan ekstrakurikuler seni tari melalui 4 tahapan tersebut menyisipkan pembiasaan dan pemberian contoh tindakan langsung yang mencerminkan nilai karakter yang sesuai dengan PPK Kurikulum 2013 kepada peserta didik.

Nilai-nilai pendidikan karakter yang terdapat pada ekstrakurikuler seni tari tradisional di SDN Sawojajar 3 Malang yaitu nilai karakter religius, nilai karakter nasionalis, nilai karakter mandiri, nilai karakter gotong royong, nilai karakter integritas dengan sub- nilai karakter persahabatan, mencintai lingkungan, menjaga kekayaan budaya bangsa, unggul dan berprestasi, disiplin, etos kerja (kerja keras), menghargai, kerja sama, tolong menolong, kejujuran, dan tanggung jawab. Namun untuk nilai karakter mandiri sub- nilai kreatif belum muncul karena sub- nilai kreatif bukan menjadi tujuan dari penerapan nilai karakter pada kegiatan ekstrakurikuler seni tari tradisional di SDN Sawojajar 3 Malang.

\section{Daftar Rujukan}

Budhiman, A. (2017) Gerakan penguatan pendidikan karakter. Jakarta: Direktorat Pembinaan Siswa.

Fadilah, N. (2016). Pelaksanaan Pembelajaran Ektrakulikuler Seni Tari Tradisional dalam Membentuk Karakter pada Siswa Kelas Tinggi di SDN Tambakaji 01 Semarang. Semarang: Universitas Negeri Semarang.

Hartini, H., \& Rudyanto, H. E. (2018). Tari Orek-Orek Sebagai Implementasi Pendidikan Karakter Berbasis Kearifan Lokal pada Siswa Sekolah Dasar di Kabupaten Ngawi. Jurnal Edukasi: Kajian Ilmu Pendidikan $4(2), 15-28$.

Jasman. (2018). Pendidikan karakter: implementasi oleh guru, kurikulum, pemerintah dan sumber daya pendidikan. Sukabumi: CV Jejak.

Komalasari, K \& Saripudin. (2017). Pendidikan Karakter Konsep dan Aplikasi Living Velue Education. Bandung: PT Refika Aditama.

Lestari, Y. S., \& Sindhuredja, F. X. (2016). Implementasi Pendidikan karakter Melalui Kegiatan ekstrakurikuler Seni Tari di Sekolah Dasar Negeri 1 Trirenggo Tahun pelajaran2015/2016. TRIHAYU: Jurnal Pendidikan Ke-SD-an, 3(1).

Rosala, D. (2016). Pembelajaran seni budaya berbasis kearifan lokal dalam upaya membangun pendidikan karakter siswa di sekolah dasar. Ritme, 2(1)

Sahlan, A. K. (2018). Mendidik Perspektif Psikologi. Yogyakarta: Deepublish.

Sugiyono. (2017). Metode Penelitian Kualitatif. Bandung: Alfabeth.

Sugiyono. (2016). Metode Penelitian Kualitatif. Bandung: Alfabeth.

Sugiyono. (2009). Metode Penelitian Kualitatif. Bandung: Alfabeth.

Sulistyaningsih, I. (2018). Nilai-nilai Pendidikan Karakter Dalam Ekstrakurikuler Seni Tari MI AL-Ihsan Medari. Yogyakarta: Universitas Islam Negeri Sunan Kalijaga.

Sumanto. (2014). Pendidikan Seni Rupa di Sekolah Dasar. Malang: Rosindo. 